\title{
Identifying Hot-Spots of Metal Contamination in Campus Dust of Xi'an, China
}

\author{
Hao Chen, Xinwei Lu *, Tianning Gao and Yuyu Chang \\ School of Tourism and Environment, Shaanxi Normal University, Xi'an 710062, China; \\ chenhao8848@126.com (H.C.); tianning_gao@sina.com (T.G.); changyuyu@snnu.edu.cn (Y.C.) \\ * Correspondence: luxinwei@snnu.edu.cn; Tel.: +86-29-8531-0525 \\ Academic Editor: Kim Natasha Dirks \\ Received: 14 April 2016; Accepted: 30 May 2016; Published: 3 June 2016
}

\begin{abstract}
The concentrations of heavy metals (As, $\mathrm{Ba}, \mathrm{Co}, \mathrm{Cr}, \mathrm{Cu}, \mathrm{Mn}, \mathrm{Ni}, \mathrm{Pb}, \mathrm{V}$, and $\mathrm{Zn}$ ) in campus dust from kindergartens, elementary schools, middle schools, and universities in the city of $\mathrm{Xi}^{\prime}$ an, China, were determined by X-ray fluorescence spectrometry. The pollution levels and hotspots of metals were analyzed using a geoaccumulation index and Local Moran's I, an indicator of spatial association, respectively. The dust samples from the campuses had metal concentrations higher than background levels, especially for $\mathrm{Pb}, \mathrm{Zn}, \mathrm{Co}, \mathrm{Cu}, \mathrm{Cr}$, and $\mathrm{Ba}$. The pollution assessment indicated that the campus dusts were not contaminated with $\mathrm{As}, \mathrm{Mn}, \mathrm{Ni}$, or $\mathrm{V}$, were moderately or not contaminated with $\mathrm{Ba}$ and $\mathrm{Cr}$ and were moderately to strongly contaminated with $\mathrm{Co}, \mathrm{Cu}, \mathrm{Pb}$, and $\mathrm{Zn}$. Local Moran's I analysis detected the locations of spatial clusters and outliers and indicated that the pollution with these 10 metals occurred in significant high-high spatial clusters, low-high, or even high-low spatial outliers. As, $\mathrm{Cu}, \mathrm{Mn}, \mathrm{Ni}, \mathrm{Pb}, \mathrm{V}$, and $\mathrm{Zn}$ had important high-high patterns in the center of $\mathrm{Xi}^{\prime} \mathrm{an}$. The western and southwestern regions of the study area, i.e., areas of old and high-tech industries, have strongly contributed to the Co content in the campus dust.
\end{abstract}

Keywords: metals; dust; hotspot; spatial cluster; Local Moran's I

\section{Introduction}

Atmospheric pollution is a major hazard in urban environments, and atmospheric fallout plays an important role in the transport and fate of air pollutants. Atmospheric pollution is very serious in many densely populated cities, especially those with rapid industrialization and urbanization that have poor air quality and heavy depositions of dust [1-4]. Dust, which contains trace metals $[5,6]$, accumulates in streets, gardens, schools, and residential areas with which people have frequent contact [7]. Dust particulates have been well recognized to influence human health [8-10], particularly due to their high contents of metals [11-14].

We previously studied the geochemical features of campus dust in the city of Xi'an in China [15] by analyzing databases containing data for many samples of dust from the campuses of a variety of educational institutions. Urban dust is spatially heterogeneous, so identifying the spatial patterns and hotspots of pollution in campus dust is difficult. A geographical information system (GIS) and multivariate analyses are useful for identifying spatial patterns of pollution and possible pollution sources [16,17]. Geostatistics is a widely used analytical method in GIS [18-21], but it cannot discriminate between positive or negative spatial correlations, detect spatial outliers or identify values that differ from those nearby. Local Moran's I index, a local test statistic for spatial autocorrelation, is more widely used than geostatistics to identify spatial clusters and outliers of a variable [22-24]. It examines individual locations and identifies hotspots based on comparisons with neighboring samples [25]. The Local Moran's I index has been successfully applied in the identification of hotspots of diseases [26,27], mortality rates [28,29], and in the environmental sciences [30,31]. 
Campuses contain some of the few playgrounds that students visit daily. Despite the serious effects of pollution on health, especially for children and young adults, studies in these areas are lacking, and information for metal contamination in academic urban campuses is limited. We assessed the levels of metal pollutants in dust sampled from a wide range of campuses in $\mathrm{Xi}^{\prime}$ an, including kindergartens, elementary schools, middle schools, and universities. Our main objectives were to determine the concentrations of $\mathrm{As}, \mathrm{Ba}, \mathrm{Co}, \mathrm{Cr}, \mathrm{Cu}, \mathrm{Mn}, \mathrm{Ni}, \mathrm{Pb}, \mathrm{V}$, and $\mathrm{Zn}$ (metals potentially harmful to the environment and human health) in campus dust, identify the pollution hotspots of heavy metals in the dust using Local Moran's I and GIS and determine the local spatial patterns of heavy metals in the dust and the possible reasons for their formation.

\section{Materials and Methods}

\subsection{The Study Area}

$\mathrm{Xi}^{\prime}$ an is the capital of Shaanxi Province and the largest city in northwestern China. It is in the center of the Guanzhong Plain $\left(108^{\circ} 52^{\prime}-108^{\circ} 60^{\prime} \mathrm{E}\right.$ and $\left.34^{\circ} 13^{\prime}-34^{\circ} 19^{\prime} \mathrm{N}\right)$ in a topographic basin surrounded by the Qinling Mountains to the south and the Loess Plateau to the north. The Loess Plateau is the major source of Asian dust [32], which is heavily contaminated with airborne particulate matter (PM), especially in spring when dust storms are frequent [33]. The climate of $\mathrm{Xi}^{\prime}$ an city is a typical temperate continental semi-humid climate with the annual average temperature and precipitation of $13-15^{\circ} \mathrm{C}$ and $500-700 \mathrm{~mm}$, respectively. The predominant wind direction in winter and autumn is northeast, while in summer and spring it is southwest [34]. Xi'an was established more than 2000 years ago, but rapid industrialization, urbanization and high-tech development in recent decades have pressured the city to adopt environmental protections and to repair environmental damage [35]. Xi'an had a total urban area of $3580 \mathrm{~km}^{2}$ and a population of 8,069,300 in 2013. The number of motorized vehicles has grown from 0.52 million in 2004 to 1.86 million in 2013 [36]. Xi'an contained 1295 kindergartens, 1291 elementary schools, 440 middle schools, and 63 universities in 2013, with 805,000 nursery and primary-school students, 484,000 middle-school students, and 838,000 university students [36].

\subsection{Dust Sampling and Analysis}

We collected 157 dust samples from the nurseries, primary schools, middle schools, and universities using a clean plastic dustpan and brush [37-39] from windowsills, balconies, doorsteps, and playgrounds that were most accessible to the students (Figure 1). The samples were collected from each campus during the same dry season from October 2011 to October 2012 and were sealed in polyethylene bags for transport and storage. A Global Positioning System (GPS) was used to identify the locations of the sites of the dust samples. Each sample was air-dried in the laboratory for two weeks, sieved through a $1.0 \mathrm{~mm}$ nylon mesh to remove refuse and small stones and then divided into two subsamples.

All sieved samples for the geochemical analysis were finely ground to pass through a 200 $(0.075 \mathrm{~mm})$ mesh sieve to meet the requirements for X-ray fluorescence (XRF). Each $4.0 \mathrm{~g}$ milled dust sample and $2.0 \mathrm{~g}$ of boric acid were placed in a mold and pressed into 32-mm diameter pellet under $30 \mathrm{t}$ of pressure. $\mathrm{As}, \mathrm{Ba}, \mathrm{Co}, \mathrm{Cr}, \mathrm{Cu}, \mathrm{Mn}, \mathrm{Ni}, \mathrm{Pb}, \mathrm{V}$, and $\mathrm{Zn}$ concentrations were determined using a PANalytical PW2403 XRF analyzer, the relative proportions of dust were determined according to methods [6,40-42]. Table 1 listed the determination parameters and measuring conditions. The Chinese national reference materials GSS-1 and GSD12 [6], with an analytical precision $>5 \%$, were used for accuracy control. The repeatability of the measurements was confirmed by analyzing separate aliquots of $25 \%$ of the total sample set. 


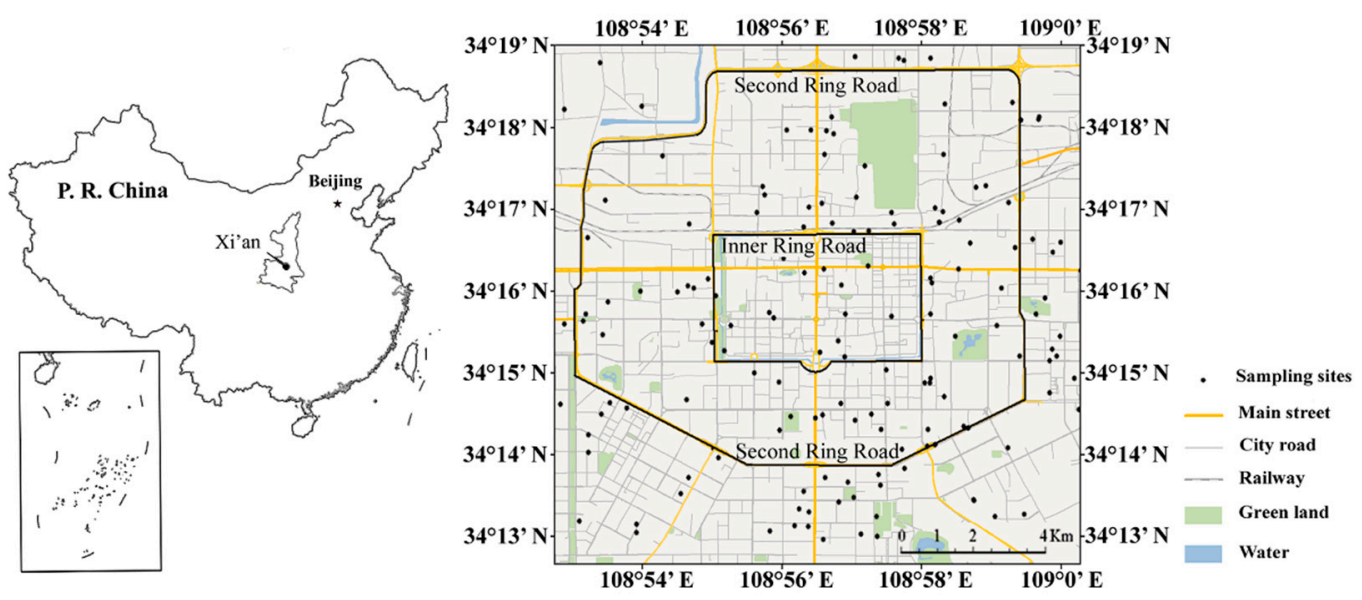

Figure 1. Maps indicating the location of Xi'an and the sampling sites in Xi'an.

Table 1. Measuring condition of elements.

\begin{tabular}{cccccccccc}
\hline Channel & Type & Line & X-Tal. & $\begin{array}{c}\text { Collimator } \\
(\boldsymbol{\mu m})\end{array}$ & Detector & $\begin{array}{c}\text { X-ray } \\
\text { Tube Filter }\end{array}$ & $\begin{array}{c}\text { Voltage } \\
(\mathbf{k V})\end{array}$ & $\begin{array}{c}\text { Current } \\
(\mathbf{m A})\end{array}$ & $\begin{array}{c}\text { Angle 2 } \\
\left({ }^{\circ}\right)\end{array}$ \\
\hline $\mathbf{A s}$ & Gonio & $\mathrm{K} \alpha$ & $\mathrm{LiF} 200$ & 300 & $\mathrm{SC}$ & None & 60 & 50 & 33.963 \\
$\mathbf{B a}$ & Gonio & $\mathrm{L} \alpha$ & $\mathrm{LiF} 200$ & 300 & $\mathrm{FC}$ & None & 50 & 60 & 87.200 \\
$\mathbf{C o}$ & Gonio & $\mathrm{K} \alpha$ & $\mathrm{LiF} 200$ & 300 & $\mathrm{SC}$ & None & 60 & 50 & 52.792 \\
$\mathbf{C r}$ & Gonio & $\mathrm{K} \alpha$ & $\mathrm{LiF} 200$ & 300 & $\mathrm{SC}$ & None & 60 & 50 & 69.368 \\
$\mathbf{C u}$ & Gonio & $\mathrm{K} \alpha$ & $\mathrm{LiF} 200$ & 300 & $\mathrm{SC}$ & None & 60 & 50 & 45.035 \\
$\mathbf{M n}$ & Gonio & $\mathrm{K} \alpha$ & $\mathrm{LiF} 200$ & 300 & $\mathrm{SC}$ & None & 60 & 50 & 62.982 \\
$\mathbf{N i}$ & Gonio & $\mathrm{K} \alpha$ & $\mathrm{LiF} 200$ & 300 & $\mathrm{SC}$ & None & 60 & 50 & 48.663 \\
$\mathbf{P b}$ & Gonio & $\mathrm{L} \beta$ & $\mathrm{LiF} 200$ & 300 & $\mathrm{SC}$ & None & 60 & 50 & 28.251 \\
$\mathbf{V}$ & Gonio & $\mathrm{K} \alpha$ & $\mathrm{LiF} 200$ & 300 & $\mathrm{FC}$ & None & 50 & 60 & 123.171 \\
$\mathbf{Z n}$ & Gonio & $\mathrm{K} \alpha$ & $\mathrm{LiF} 200$ & 300 & $\mathrm{SC}$ & None & 60 & 50 & 41.801 \\
\hline
\end{tabular}

\subsection{Outlier Detection}

Environmental geochemical data sets often contain outliers [43] that should be detected and removed or replaced before statistical analysis. Many methods can detect outliers. The commonly used range method identifies outliers as those lower than the average values minus three standard deviations and those higher the average values plus three standard deviations. We deleted the outliers and replaced them with the highest values in the data sets [43].

\subsection{Geoaccumulation Analysis}

The geoaccumulation index $\left(I_{g e o}\right)$ developed by Müller [44] is widely used to assess the level of heavy-metal contamination in dust $[12,33,35,45,46]$. I geo was calculated following Müller [44] as:

$$
I_{g e o}=\log _{2}\left(C_{n} /\left(1.5 B_{n}\right)\right)
$$

where $C_{n}$ is the concentration of heavy metal $n$ in the dust sample and $B_{n}$ is the corresponding background concentration of heavy metal $n$ in Shaanxi soil [47]. I geo consists of the following classifications $[33,35,48]$ : uncontaminated $\left(I_{g e o} \leqslant 0\right)$, uncontaminated to moderately contaminated $\left(0<I_{\text {geo }} \leqslant 1\right)$, moderately contaminated $\left(1<I_{\text {geo }} \leqslant 2\right)$, moderately to heavily contaminated $\left(2<I_{\text {geo }} \leqslant 3\right)$, heavily contaminated $\left(3<I_{g e o} \leqslant 4\right)$, heavily to extremely contaminated $\left(4<I_{g e o} \leqslant 5\right)$, and extremely contaminated $\left(I_{g e o}>5\right)$. 


\subsection{Local Spatial Autocorrelation}

Local Moran's I can identify the autocorrelation between a single location and its neighbors [49]. It is calculated as:

$$
I_{i}=\frac{n\left(x_{i}-\bar{x}\right) \sum_{j=1}^{n} w_{i j}\left(x_{j}-\bar{x}\right)}{\sum_{i=1}^{n}\left(x_{i}-\bar{x}\right)^{2}}
$$

where $n$ is the number of observations of the entire region, $x_{i}$ is the value of variable $x$ at location $i, x_{j}$ is the value of variable $x$ at all other locations (where $j \neq i$ ), $\bar{x}$ is the mean of $x$, and $w_{i j}$, an element of spatial-weight matrix $w$, is the spatial weight between locations $i$ and $j$.

A map showing locations with significant Local Moran's I statistics, classified by type of spatial correlation, is defined as a cluster map of local indicators of spatial autocorrelation (LISA) [22]. Four categories of local spatial autocorrelation are distinguished: two suggest clusters that include high-high spatial clusters (high values in a high-value neighborhood) and low-low spatial clusters (low values in a low-value neighborhood) and two suggest spatial outliers that include low-high spatial outliers (a low value in a high-value neighborhood) and high-low spatial outliers (a high value in a low-value neighborhood). The LISA map provides information for the statistically significant clusters/outliers and indicates the variability and distribution of the types of spatial correlations in the study area. For dust pollution, low-low spatial clusters are "cool spots", and high-high spatial clusters can be regarded as "regional hotspots".

\subsection{Data Transformation}

Means and variances are strongly affected by positively skewed data (with some very high values), so data transformation was necessary before Local Moran's I could be calculated. Box-Cox transformation is a common and effective method of power transformation [43,50-52]. The Box-Cox transformation is given by:

$$
y= \begin{cases}\frac{x^{\lambda}-1}{\lambda} & \lambda \neq 0 \\ \ln (x) & \lambda=0\end{cases}
$$

where $y$ is the transformed value and $x$ is the value to be transformed. For a given data set $\left(x_{1}, x_{2}, \ldots x_{n}\right)$, the parameter $\lambda$ is estimated based on the assumption that the transformed values $\left(y_{1}, y_{2}, \ldots y_{n}\right)$ are normally distributed. The transformation becomes logarithmic when $\lambda=0$.

\subsection{Statistical Analysis}

Principal component analyses (PCA) are widely used to reduce data and to extract a small number of latent factors (principal components, PCs) for analyzing the relationships among observed variables [30,53]. The PCs are calculated based on a correlation matrix. Varimax with Kaiser normalization was used as the rotation method in the analysis [54]. A PCA can reduce the number of correlated variables to a smaller set of orthogonal factors, simplifying the interpretation of a given multidimensional system by displaying the correlations among the original variables [5].

\subsection{Data Computation}

All maps were produced using ArcGIS (version 9.3) (Esri, RedLands, CA, USA). Thiessen polygons of the samples were created, and spatial clusters/outliers were identified using Geoda (version 0.95i) (Arizona State University, Phoenix, AZ, USA) [55]. Statistical analyses were performed with SPSS 19.0 for Windows (IBM, Armonk, NY, USA). 


\section{Results and Discussion}

\subsection{Metal Concentrations in the Campus Dust}

The metal concentrations in the campus dust from Xi'an are shown in Figure 2. The concentrations of $\mathrm{As}, \mathrm{Ba}, \mathrm{Co}, \mathrm{Cr}, \mathrm{Cu}, \mathrm{Mn}, \mathrm{Ni}, \mathrm{Pb}, \mathrm{V}$, and $\mathrm{Zn}$ were within the ranges 1.4-29.7, 542.7-2195.9, 19.3-81.1, 77.4-402.4, 22.3-138.3, 349.5-795.8, 16.8-64.2, 37.2-494.1, 50.2-99.3, and 65.9-1838.3 mg. $\mathrm{kg}^{-1}$, respectively. The arithmetic mean concentrations of all analyzed metals in the dust were higher than their corresponding background concentrations in Shaanxi soil [47], except for As, $\mathrm{Mn}, \mathrm{Ni}$, and V. The coefficients of variation (CVs) were large for all heavy metals except $\mathrm{Mn}(17 \%), \mathrm{Ni}(26 \%)$, and $\mathrm{V}$ $(15 \%)$, indicating that the variations in the concentrations of As $(50 \%), \mathrm{Ba}(35 \%), \mathrm{Co}(34 \%), \mathrm{Cr}(41 \%)$, $\mathrm{Cu}(40 \%), \mathrm{Pb}(61 \%)$, and $\mathrm{Zn}(77 \%)$ were high. The ratios of arithmetic mean concentrations of the heavy metals in the dust to the corresponding background concentrations in Shaanxi soil decreased in the order $\mathrm{Pb}>\mathrm{Zn}>\mathrm{Co}>\mathrm{Cu}>\mathrm{Cr}>\mathrm{Ba}>\mathrm{Ni}>\mathrm{As}>\mathrm{V}>\mathrm{Mn}$.

The ranges and mean concentrations of $\mathrm{Cu}, \mathrm{Pb}, \mathrm{Zn}, \mathrm{Cr}$, and $\mathrm{Mn}$ were lower in the campus dust than $\mathrm{Xi}^{\prime}$ an road dust [33], perhaps because most schools are far from the main streets and because road dust is much more easily polluted than campus dust. The concentrations of As were similar in the campus and road dust [33].

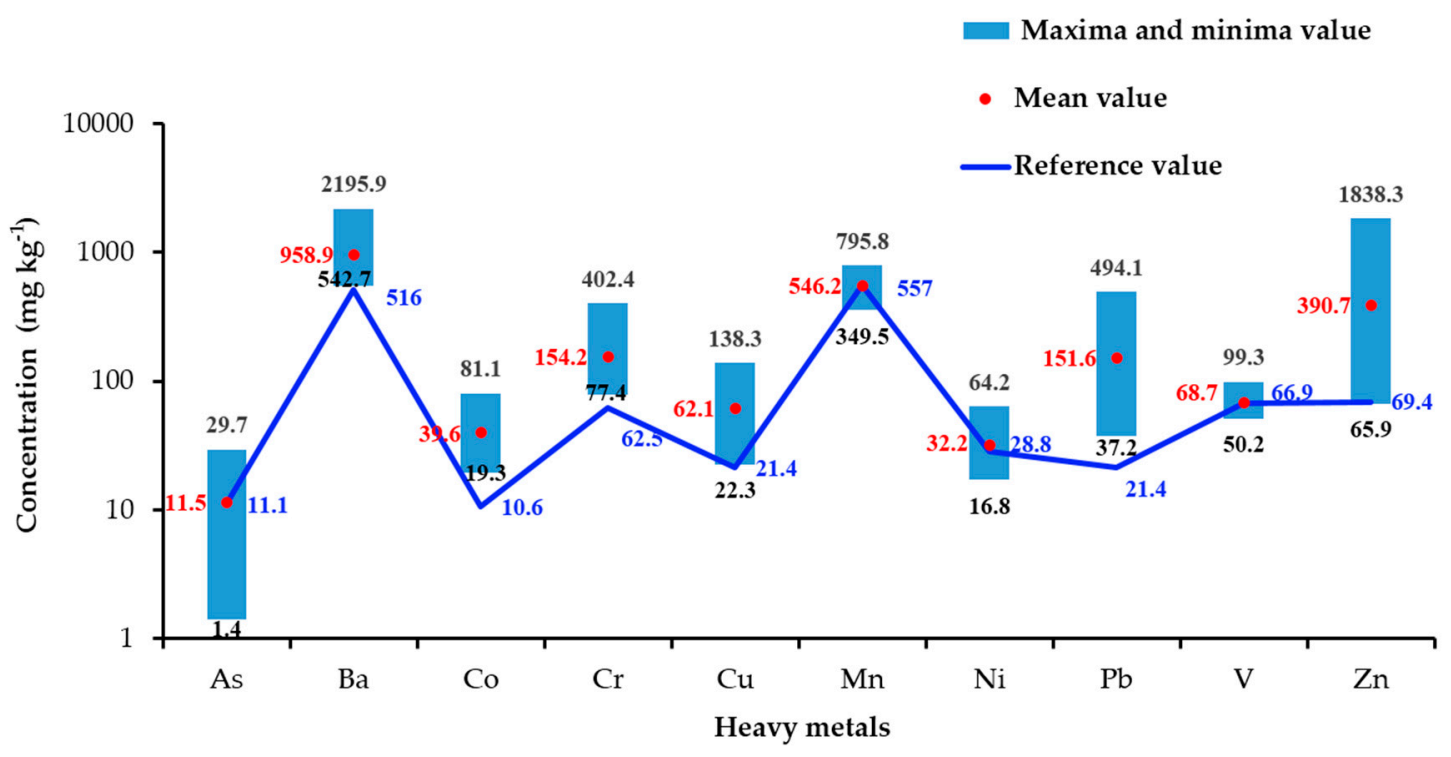

Figure 2. Metal concentrations in the campus dust in $\mathrm{Xi}^{\prime}$ an and reference concentrations.

$\mathrm{Cu}, \mathrm{Pb}$, and $\mathrm{Zn}$ were the most widely analyzed metals in the dust. Table 2 compares the $\mathrm{Cu}, \mathrm{Pb}$, and $\mathrm{Zn}$ concentrations in our samples with those from campuses in other cities [56-61]. The levels of $\mathrm{Cu}$ and $\mathrm{Zn}$ were higher in $\mathrm{Xi}^{\prime}$ an than the other cities, except for Tehran and Hong Kong. The mean concentration of $\mathrm{Pb}$ was higher in $\mathrm{Xi}^{\prime}$ an $\left(151.6 \mathrm{mg} \cdot \mathrm{kg}^{-1}\right)$ than in Hermosillo $\left(36.15 \mathrm{mg} \cdot \mathrm{kg}^{-1}\right)$, Shah Alam (31.24 mg. kg $\left.{ }^{-1}\right)$, and Beijing $\left(69.4 \mathrm{mg} \cdot \mathrm{kg}^{-1}\right)$ but lower than in Tehran $\left(257.4 \mathrm{mg} \cdot \mathrm{kg}^{-1}\right)$, Hong Kong $\left(200 \mathrm{mg} \cdot \mathrm{kg}^{-1}\right)$, and Kaifeng $\left(243 \mathrm{mg} \cdot \mathrm{kg}^{-1}\right)$.

Table 2. Comparison of mean $\mathrm{Cu}, \mathrm{Pb}$, and $\mathrm{Zn}$ concentrations $\left(\mathrm{mg} \cdot \mathrm{kg}^{-1}\right)$ in campus dust in various cities.

\begin{tabular}{cccccccc}
\hline Element & Hermosillo & Tehran & Shah Alam & Hong Kong & Beijing & Kaifeng & Xi'an \\
\hline $\mathbf{C u}$ & 26.34 & 225.3 & 30.19 & 247.38 & 57.3 & 38.92 & 62.1 \\
$\mathbf{P b}$ & 36.15 & 257.4 & 31.24 & 199.96 & 69.4 & 242.99 & 151.6 \\
$\mathbf{Z n}$ & 387.98 & 873.2 & 148.71 & 2293.56 & 301 & 297.32 & 390.7 \\
\hline
\end{tabular}




\subsection{Geoaccumulation Index Assessment ( $\left.I_{g e o}\right)$}

$I_{\text {geo }}$ was calculated for all analyzed metals in each dust sample relative to the background concentrations in the local soil [47] (Figure 3). $I_{\text {geo }}$ ranged from -3.57 to 0.83 for As, -0.51 to 1.5 for $\mathrm{Ba}, 0.28$ to 2.35 for $\mathrm{Co},-0.28$ to 2.10 for $\mathrm{Cr},-0.53$ to 2.11 for $\mathrm{Cu},-1.26$ to -0.07 for $\mathrm{Mn},-1.36$ to 0.57 for $\mathrm{Ni}, 0.21$ to 3.94 for $\mathrm{Pb},-1.00$ to -0.02 for $\mathrm{V}$, and -0.66 to 4.11 for $\mathrm{Zn}$. I geo averaged -0.71 , $0.24,1.24,0.63,0.84,-0.63,-0.47,2.04,-0.56$, and 1.62 for As, Ba, Co, Cr, Cu, Mn, Ni, Pb, V, and Zn, respectively. Mean $I_{\text {geo }}$ was $>2$ for $\mathrm{Pb}$ and $<0$ for $\mathrm{As}, \mathrm{Mn}, \mathrm{Ni}$, and $\mathrm{V}$. Maximum $I_{\text {geo }}$ was $>2$ for $\mathrm{Co}, \mathrm{Cr}$, and $\mathrm{Cu}$, near 4 for $\mathrm{Pb}$ and $>4$ for $\mathrm{Zn}$, indicating that the sources of $\mathrm{Co}, \mathrm{Cr}, \mathrm{Cu}, \mathrm{Pb}$, and $\mathrm{Zn}$ in the dust, especially $\mathrm{Pb}$ and $\mathrm{Zn}$, were mostly associated with human activity. The $I_{\text {gee }}$ values of $\mathrm{Ba}$ in $31 \%$ and $62 \%$ dust samples were $<0$ and in $0-1$, respectively.

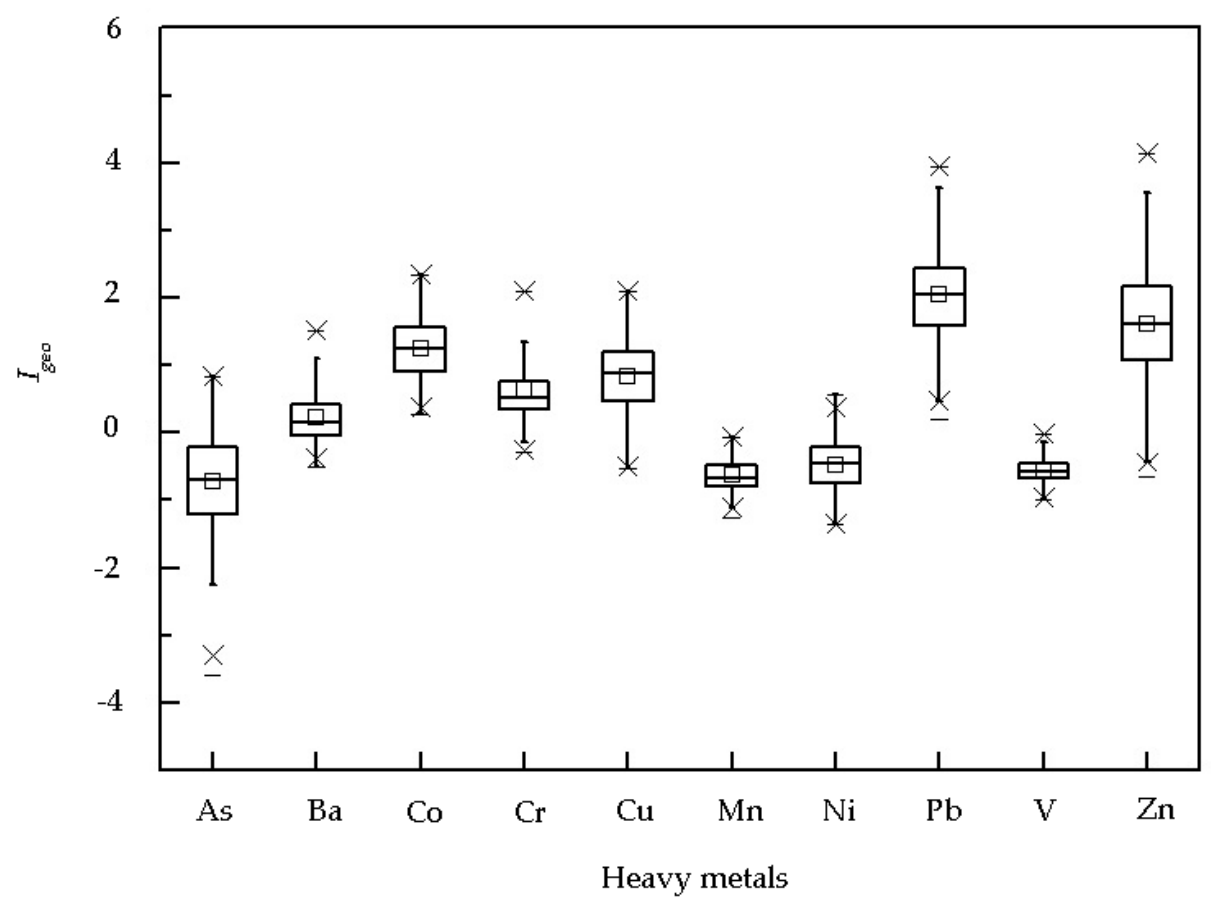

Figure 3. Geoaccumulation indices $\left(I_{g e o}\right)$ of metals in the campus dust.

\subsection{Effects of the Weight Function on Hotspot Identification}

To investigate the effects of different distance bands on the results of Local Moran's I, we established three distance bands: 1000,2000 , and $5000 \mathrm{~m}$. When calculating the index for each location, we assigned a value of 1 to the weights for neighboring locations if the distances were within a band, otherwise the weights were assigned a value of 0 . Our choice of the distance bands was arbitrary, because no specific criteria were available for determining optimal distances. The distances should generally not be shorter than the sampling interval (about $500 \mathrm{~m}$ in this study) and not longer than half the maximum distance between all sample pairs (about $6000 \mathrm{~m}$ in this study). A distance band of $2000 \mathrm{~m}$ was most reasonable based on the results of previous distance-band analyses of the spatial distribution of metals in urban dusts $[16,17]$.

\subsection{Local Indicators of Spatial Association (LISA)}

The LISA analysis indicated the spatial variability in detail. The concentrations of heavy metals in the dust were obviously higher than their corresponding background concentrations in Shaanxi soil, but only As, $\mathrm{Cu}$, and $\mathrm{Ni}$ had a significant spatial pattern (Table 3). The percentages of samples with significant spatial clusters (high-high or low-low) were $44.0 \%$ for $\mathrm{Ni}, 43.3 \%$ for As, $36.3 \%$ for $\mathrm{Cu}$ but only about $20 \%$ for $\mathrm{Co}, \mathrm{Mn}, \mathrm{Pb}$, and $\mathrm{V}$. The high-high pattern of most of the heavy metals 
dominated the overall spatial pattern. More than $10 \%$ of the samples of most metals were significant spatial outliers (low-high and high-low), and the low-high pattern was particularly apparent for $\mathrm{Cr}$, $\mathrm{Mn}, \mathrm{Pb}$, and $\mathrm{Zn}$ (Table 3). These significant spatial patterns may indicate enrichment of the heavy metals in the campus dust.

Table 3. Sample percentages (\%) of the categories of local spatial patterns from the LISA analysis.

\begin{tabular}{ccccccccccc}
\hline $\begin{array}{c}\text { Spatial } \\
\text { Autocorrelation }\end{array}$ & As & Ba & Co & Cr & Cu & Mn & Ni & Pb & V & Zn \\
\hline Not significant & 36.31 & 83.44 & 67.52 & 91.72 & 43.95 & 69.42 & 32.48 & 54.78 & 61.78 & 66.88 \\
High-high & 25.48 & 1.27 & 9.55 & 3.18 & 21.66 & 14.65 & 22.93 & 14.65 & 12.74 & 6.37 \\
Low-low & 17.83 & 7.64 & 8.92 & 0.00 & 14.65 & 4.46 & 21.02 & 9.55 & 9.55 & 9.55 \\
Low-high & 8.92 & 2.55 & 4.46 & 5.10 & 10.19 & 8.92 & 10.19 & 12.10 & 8.92 & 10.83 \\
High-low & 11.46 & 5.10 & 9.55 & 0.00 & 9.55 & 2.55 & 13.38 & 8.92 & 7.01 & 6.37 \\
\hline
\end{tabular}

The pollution statuses of the metals in the categories of local spatial patterns are presented in Table 4. Mn and V were not pollutants in any of the categories of spatial patterns. Only $4.46 \%$ of the samples containing Ni had a high-high spatial pattern. The samples with As pollution are $15.29 \%$ and the main pollution is the high-high spatial pattern (9.56\%). Although the samples with Ba pollution are $57.96 \%$ in no significantly categories of spatial pattern, there was only $1.27 \%$ in high-high spatial pattern. $\mathrm{Co}, \mathrm{Cr}, \mathrm{Cu}, \mathrm{Pb}$, and $\mathrm{Zn}$ represented a relatively high percentage of the polluted samples (Table 4). Among these, all samples were polluted by $\mathrm{Co}$ and $\mathrm{Pb}$, and more than $90 \%$ of the samples were polluted by $\mathrm{Cr}, \mathrm{Cu}$, and $\mathrm{Zn}$. The high-high spatial clusters for $\mathrm{Co}, \mathrm{Cr}, \mathrm{Cu}, \mathrm{Pb}$, and $\mathrm{Zn}$ decreased in the order $\mathrm{Cu}(21.66 \%)>\mathrm{Pb}(14.65 \%)>\mathrm{Co}(9.55 \%)>\mathrm{Zn}(6.37 \%)>\mathrm{Cr}(3.18 \%)$.

Table 4. The status of pollutant distribution (\%) in the categories of local spatial patterns.

\begin{tabular}{|c|c|c|c|c|c|c|}
\hline \multirow{2}{*}{ Heavy Metal } & \multirow{2}{*}{ Pollution Status } & \multicolumn{5}{|c|}{ Spatial Autocorrelation } \\
\hline & & Not Significant & High-High & Low-Low & Low-High & High-Low \\
\hline \multirow{2}{*}{ As } & Polluted & 3.82 & 9.56 & - & - & 1.91 \\
\hline & Unpolluted & 32.49 & 15.92 & 17.83 & 8.92 & 9.55 \\
\hline \multirow{2}{*}{$\mathbf{B a}$} & Polluted & 57.96 & 1.27 & 3.18 & 1.27 & 5.10 \\
\hline & Unpolluted & 25.48 & & 4.46 & 1.28 & - \\
\hline \multirow{2}{*}{ Co } & Polluted & 67.52 & 9.55 & 8.92 & 4.46 & 9.55 \\
\hline & Unpolluted & - & - & - & - & - \\
\hline \multirow{2}{*}{$\mathrm{Cr}$} & Polluted & 90.45 & 3.18 & - & 4.46 & - \\
\hline & Unpolluted & 1.27 & - & - & 0.64 & - \\
\hline \multirow{2}{*}{$\mathrm{Cu}$} & Polluted & 43.95 & 21.66 & 12.1 & 8.28 & 9.55 \\
\hline & Unpolluted & - & - & 2.55 & 1.91 & \\
\hline \multirow{2}{*}{ Mn } & Polluted & - & - & - & - & - \\
\hline & Unpolluted & 69.42 & 14.65 & 4.46 & 8.92 & 2.55 \\
\hline \multirow{2}{*}{$\mathrm{Ni}$} & Polluted & - & 4.46 & - & - & - \\
\hline & Unpolluted & 32.48 & 18.47 & 21.02 & 10.19 & 13.38 \\
\hline \multirow{2}{*}{$\mathrm{Pb}$} & Polluted & 54.78 & 14.65 & 9.55 & 12.1 & 8.92 \\
\hline & Unpolluted & - & - & - & - & - \\
\hline \multirow[b]{2}{*}{ V } & Polluted & - & - & - & - & - \\
\hline & Unpolluted & 61.78 & 12.74 & 9.55 & 8.92 & 7.01 \\
\hline \multirow{2}{*}{ Zn } & Polluted & 65.61 & 6.37 & 8.92 & 10.19 & 6.37 \\
\hline & Unpolluted & 1.27 & - & 0.63 & 0.64 & - \\
\hline
\end{tabular}

\subsection{Metal Hot-Spots in Campus Dust}

The LISA maps for all analyzed metals in the campus dust are presented in Figure 4, which further indicate the hot-spots of these metals. The central region extending from north to south was strongly influenced by the high-high pattern for $\mathrm{As}, \mathrm{Cu}, \mathrm{Mn}, \mathrm{Ni}, \mathrm{Pb}$, and $\mathrm{V}$, indicating that this zone 
contained most of the hot-spots of these metals. The central zone, which includes commercial centers and residential areas, has heavy traffic. The low-low patterns of As (Figure 4a) were evenly distributed in the western and eastern regions outside the inner ring road. Unlike As, the low-low patterns for $\mathrm{Ni}$ (Figure 4g), $\mathrm{Cu}$ (Figure 4e), and $\mathrm{Pb}$ (Figure $4 \mathrm{~h}$ ) were all concentrated in the eastern part of the study area, which contains an old industrial and commercial area. The numbers of low-low patterns of $\mathrm{Ni}$, $\mathrm{Cu}$, and $\mathrm{Pb}$ were notably lower in the east, and pollution by $\mathrm{Ni}, \mathrm{Cu}$, and $\mathrm{Pb}$ may be more intense in this area. The central region had fewer Mn (Figure 4f) and V (Figure 4i) hot-spots. The low-low patterns of $\mathrm{Mn}$ and $\mathrm{V}$ were sporadically distributed in the study area.

Unlike those of the other metals, the Co hot-spots (Figure 4c) were in the western and southwestern parts of the study area. The southwestern high-high pattern area was near the Second Ring road and contains a high-tech industrial area and the commercial district of $\mathrm{Xi}^{\prime}$ an. The western high-high pattern corresponded to an old industrial area and a densely populated residential area. In contrast to the high-high patterns of most metals, the low-low pattern of Co appeared in the central region.

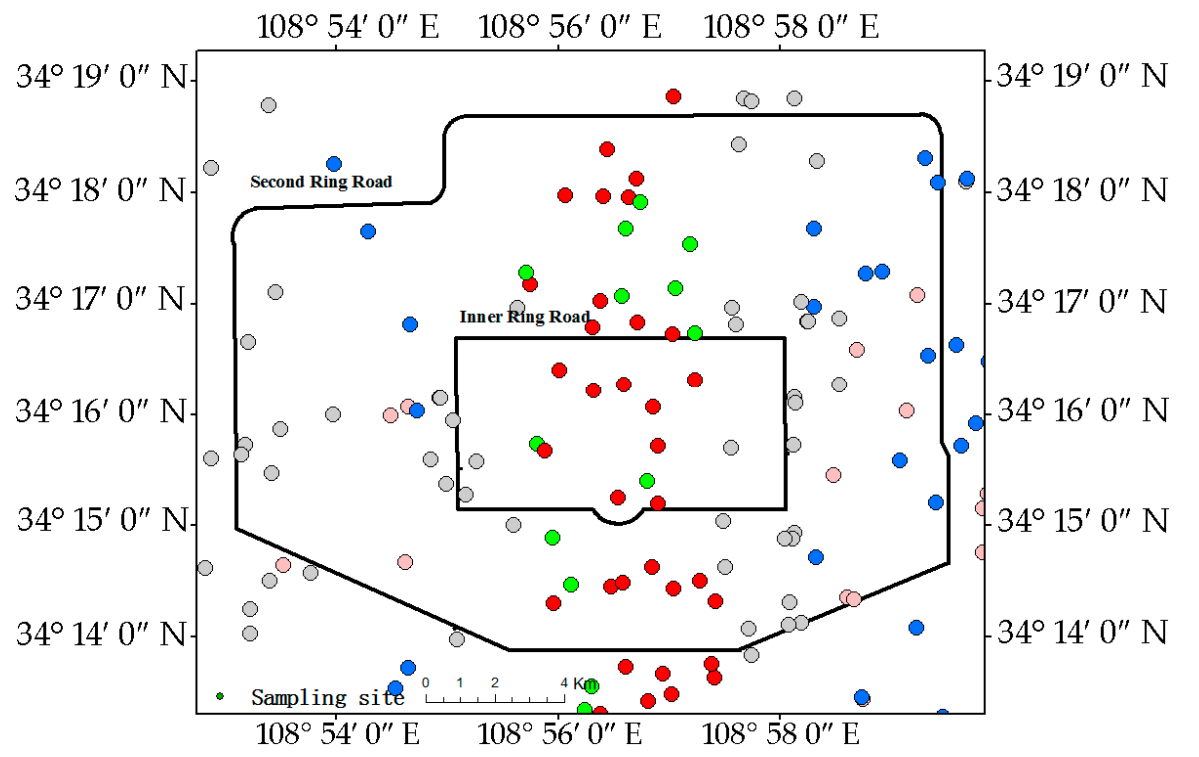

As

Not significant

- High - High

- Low - Low

- Low - High

- High - Low

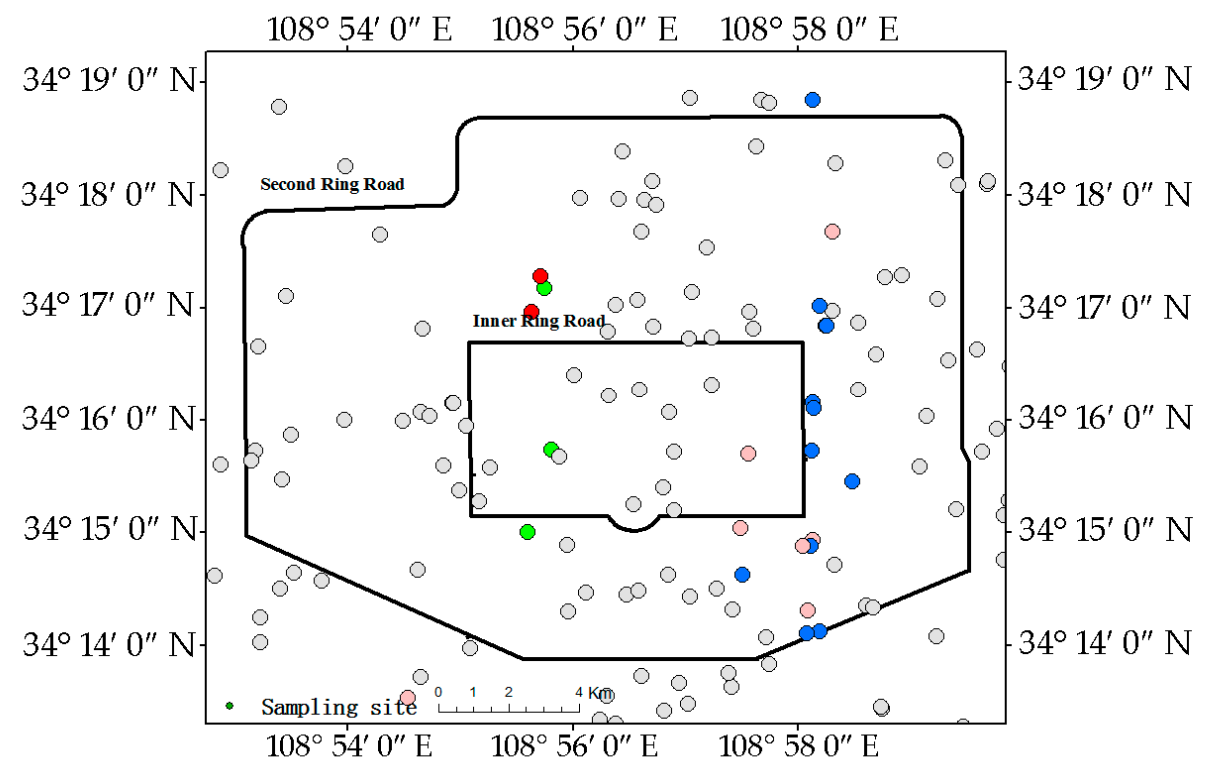

(b)

Ba

Not significant

- High - High

- Low - Low

- Low - High

High - Low

Figure 4. Cont. 

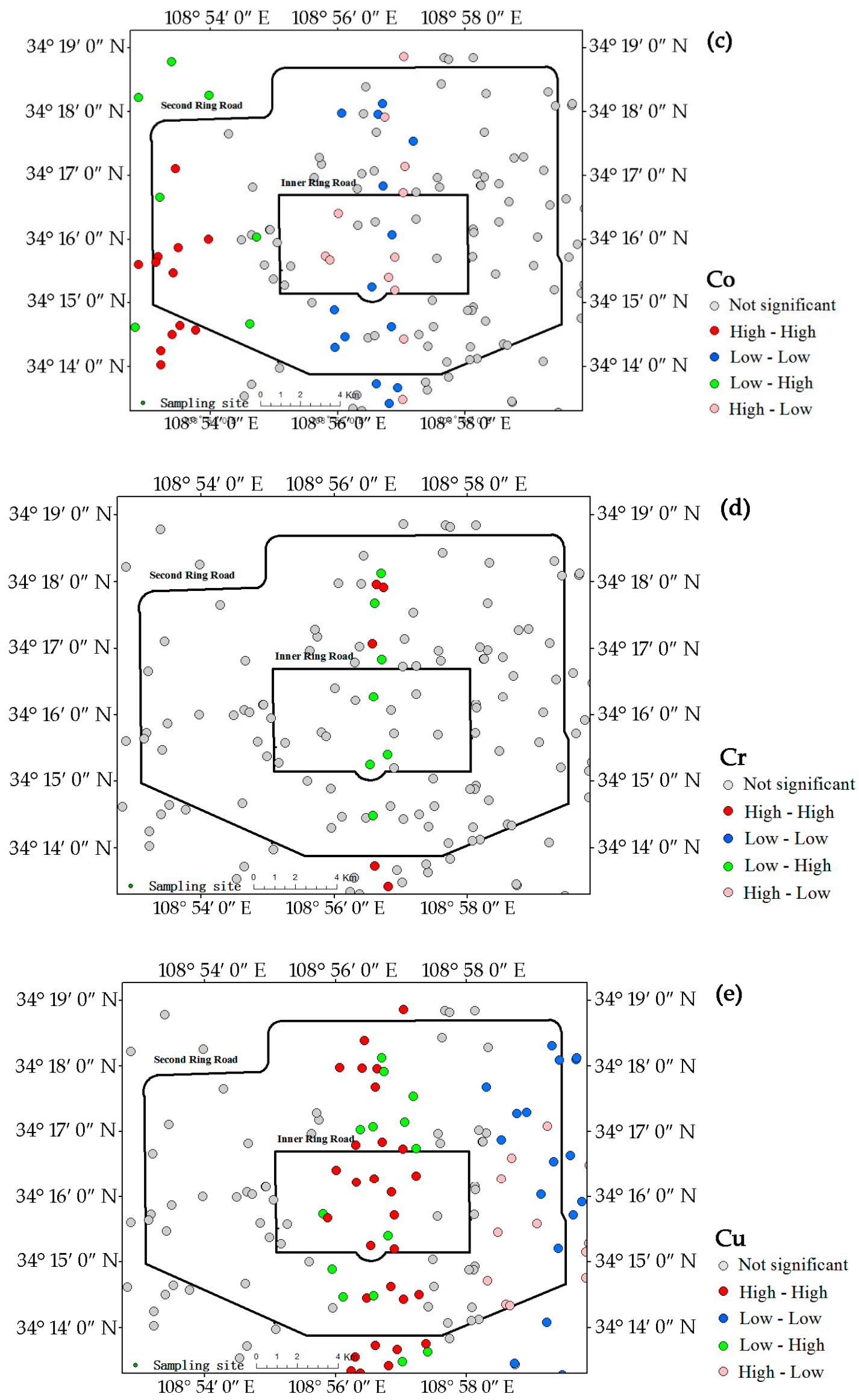

Figure 4. Cont. 

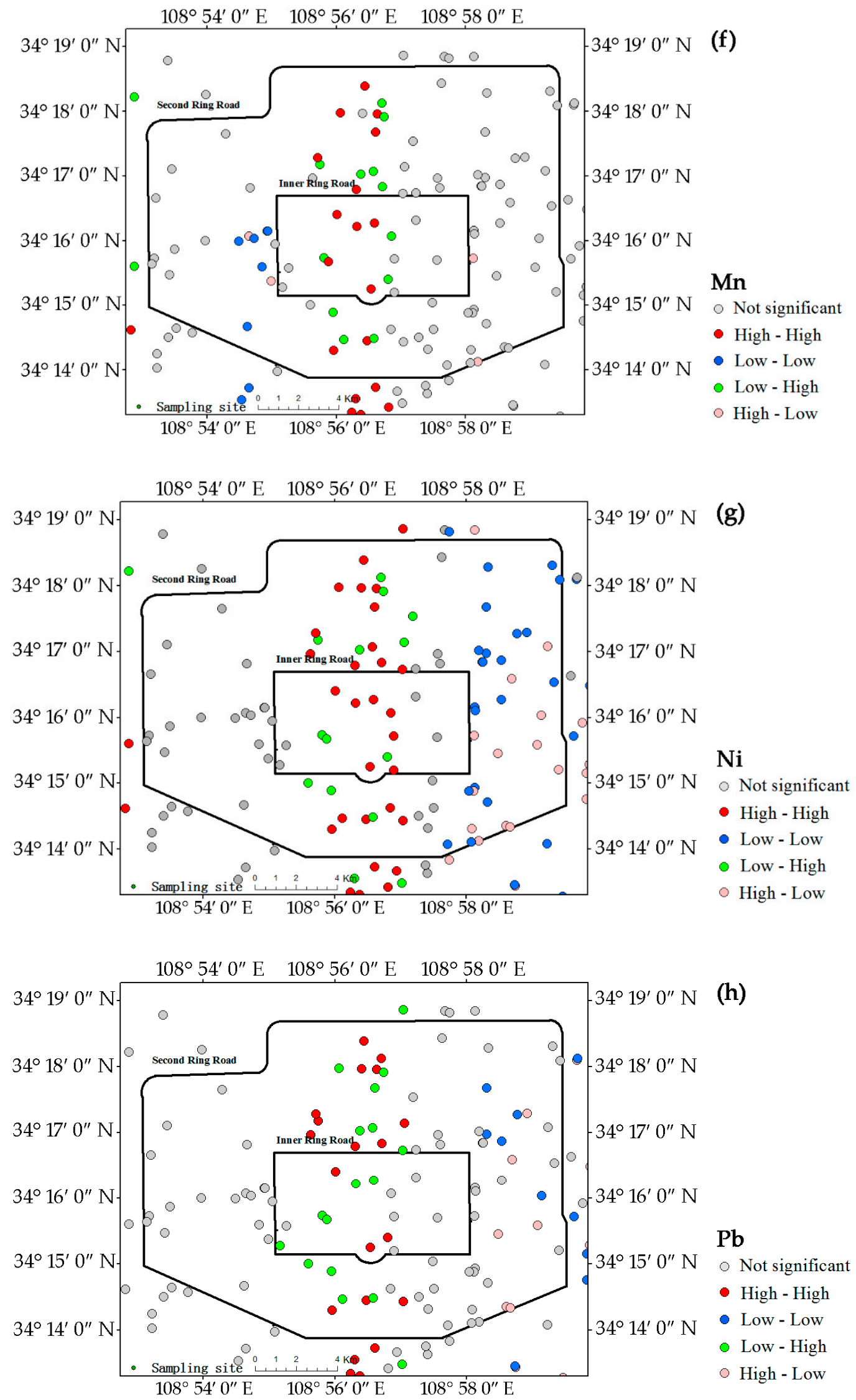

Figure 4. Cont. 

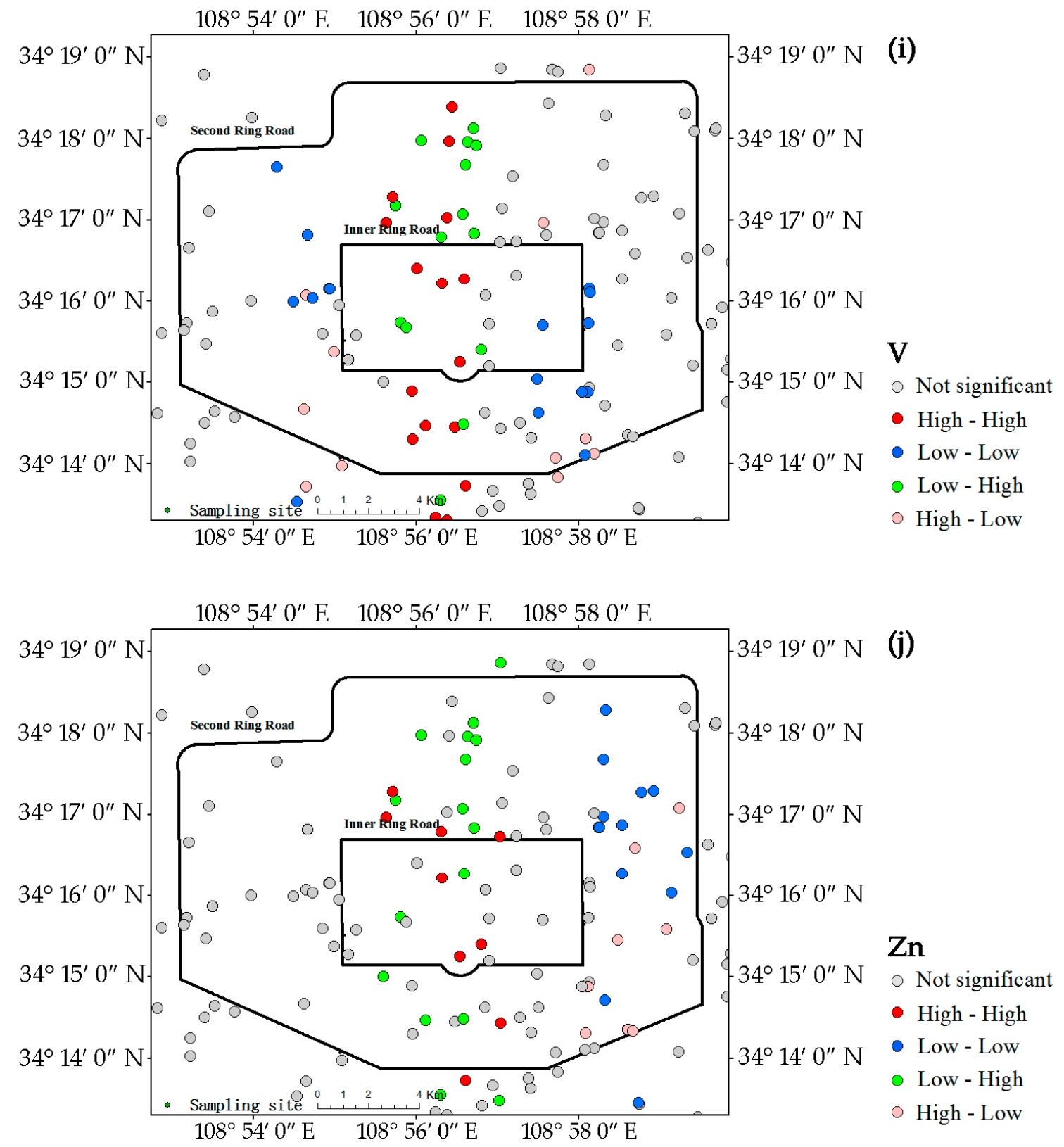

Figure 4. LISA cluster maps of Xi'an for metals in the campus dust. (a) As; (b) Ba; (c) Co; (d) Cr; (e) Cu; (f) $\mathrm{Mn}$; (g) Ni; (h) $\mathrm{Pb}$; (i) V; (j) Zn.

Ba (Figure 4b) and Cr (Figure 4d) had no obvious hot-spots, only a few low-low patterns of Ba in the eastern and southeastern parts of study area between the inner and second ring roads.

The $\mathrm{Zn}$ hot-spots (Figure 4j) were concentrated in the central region, similar to $\mathrm{Pb}$, but in reduced number compared with $\mathrm{Pb}$. The concentration, $\mathrm{CV}$ and $I_{\text {geo }}$ for $\mathrm{Zn}$ suggest that $\mathrm{Zn}$ concentration in dust is not only serious, but also generally prevalent.

\subsection{Principal Component Analysis (PCA)}

We conducted a PCA for each data set to gain insight into the sources of the metals and the major correlations among them. Table 5 shows the factor loadings with a varimax rotation and the eigenvalues and communalities calculated by SPSS. Five PCs had eigenvalues $>1$, and these five factors explained $80 \%$ of the total variance. The first factor explained $24.4 \%$ of the total variance, heavily loaded on $\mathrm{As}, \mathrm{Cu}, \mathrm{Mn}$, and Ni. Factor 2 was loaded primarily by Ba and $\mathrm{V}$ and also moderately by $\mathrm{Mn}$, 
accounting for $17.6 \%$ of the total variance. The loading was lower for $\mathrm{Mn}(0.442)$ than for $\mathrm{V}$ and $\mathrm{Ba}$ (0.878 and 0.814 , respectively), which may imply quasi-independent behavior within the group [6]. Factor 3, dominated by $\mathrm{Pb}$ and $\mathrm{Zn}$, accounted for $14.3 \%$ of the total variance. Factors 4 and 5 explained $12.5 \%$ and $11.2 \%$ of the total variance and loading for $\mathrm{Cr}$ and $\mathrm{Co}$, respectively.

Table 5. Rotated component matrix for the data of Xi'an campus dust (PCA loadings $>0.4$ are shown in bold).

\begin{tabular}{ccccccc}
\hline \multirow{2}{*}{ Element } & \multicolumn{7}{c}{ Component } & \multirow{2}{*}{ Communalities } \\
\cline { 2 - 6 } & $\mathbf{1}$ & $\mathbf{2}$ & $\mathbf{3}$ & $\mathbf{4}$ & $\mathbf{5}$ & \\
\hline $\mathbf{A s}$ & $\mathbf{0 . 8 4 5}$ & 0.115 & 0.267 & -0.117 & 0.007 & 0.812 \\
$\mathbf{B a}$ & 0.015 & $\mathbf{0 . 8 1 4}$ & 0.334 & 0.114 & 0.220 & 0.837 \\
$\mathbf{C o}$ & 0.005 & 0.029 & -0.022 & 0.010 & $\mathbf{0 . 9 5 6}$ & 0.915 \\
$\mathbf{C r}$ & 0.169 & 0.023 & 0.024 & $\mathbf{0 . 9 0 8}$ & 0.008 & 0.855 \\
$\mathbf{C u}$ & $\mathbf{0 . 7 4 2}$ & 0.004 & 0.102 & 0.345 & 0.057 & 0.759 \\
$\mathbf{M n}$ & $\mathbf{0 . 5 1 5}$ & $\mathbf{0 . 4 4 2}$ & 0.102 & 0.386 & -0.069 & 0.625 \\
$\mathbf{N i}$ & $\mathbf{0 . 8 1 6}$ & 0.268 & 0.100 & 0.247 & -0.070 & 0.813 \\
$\mathbf{P b}$ & 0.269 & 0.132 & $\mathbf{0 . 6 7 7}$ & 0.249 & -0.330 & 0.719 \\
$\mathbf{V}$ & 0.275 & $\mathbf{0 . 8 7 8}$ & -0.010 & -0.061 & -0.135 & 0.868 \\
$\mathbf{Z n}$ & 0.260 & 0.149 & $\mathbf{0 . 8 2 8}$ & -0.084 & 0.130 & 0.799 \\
Eigenvalue & 2.44 & 1.76 & 1.43 & 1.25 & 1.12 & \\
\% of variance & 24.4 & 17.6 & 14.3 & 12.5 & 11.2 & \\
\% of cumulative & 24.4 & 42.0 & 56.3 & 68.8 & 80.0 & \\
\hline
\end{tabular}

\subsection{Causes of Hot-Spot Formation}

The PCAs and the analysis of local spatial autocorrelation identified the main sources of hot-spot formation, which divided the metals into four groups. The first group contained $\mathrm{As}, \mathrm{Cu}, \mathrm{Mn}, \mathrm{Ni}, \mathrm{Pb}$, $\mathrm{V}$, and $\mathrm{Zn}$, which had important high-high patterns and were strongly enriched in the central zone. Even though As, Mn, Ni, and V had many hot-spots in this area, the arithmetic mean concentrations of these metals in the dust samples were lower than or similar to their corresponding background levels. $\mathrm{Mn}, \mathrm{Ni}$, and $\mathrm{V}$ concentrations had low $\mathrm{CVs}$, which may indicate that these metals in the central area originated naturally from the local soil. $I_{g e o}$ indicated that As had mainly natural but partly anthropogenic sources. The concentrations of $\mathrm{Cu}, \mathrm{Pb}$, and $\mathrm{Zn}$ were $>1.5$-fold higher than the corresponding background concentrations in $95 \%$ of the samples. The $\mathrm{Cu}$ and $\mathrm{Pb}$ hot-spots were mainly concentrated in the central part of the city where the road network is dense and traffic is heavy. $\mathrm{Cu}$ is commonly used in $\mathrm{Cu}$-brass automotive radiators due to its high resistance to corrosion and high thermal conductivity [62]. It is also often used in car lubricants [6]. The deterioration of the mechanical parts in vehicles over time will emit $\mathrm{Cu}$ to the surrounding environment [63], and the oxidation of lubricating oils upon exposure to air at high temperatures will form organic compounds that are corrosive to metals [64]. The use of leaded petrol has been banned in Xi'an since 2000, but the $\mathrm{Pb}$ content of the urban soil still represents substantial historical $\mathrm{Pb}$ contamination and the long half-life of $\mathrm{Pb}$ in soil [42]. $\mathrm{Pb}$ in bare soil could enter the urban dust by re-suspension. $\mathrm{Zn}$ was the second worst pollutant in the campus dust after $\mathrm{Pb}$, but it had the fewest hot-spots of this first group of metals. The Zn hot-spots were masked by their contents, which increased in most regions. Zinc alloys and galvanized components are widely used in motor vehicles. Zinc compounds are also extensively used as antioxidants and as detergent/dispersant improvers for lubricating oils [65]. Zn added to tires during vulcanization accounts for $0.4 \%-4.3 \%$ of the tire tread [64]. The wear and tear of vulcanized vehicle tires and the corrosion of galvanized automobile parts are the main sources of $\mathrm{Zn}$ in urban environments $[6,33]$.

The second group contained only $\mathrm{Ba}$, with no obvious hot-spots in the study area. The low-low patterns of $\mathrm{Ba}$ were in the eastern and southeastern areas outside the inner ring road. The $I_{g e o}$ assessment results indicated that $\mathrm{Ba}$ were uncontaminated and uncontaminated to moderately 
contaminated in the campus dust. Ba is widely used in alloys, paints, ceramics, plastic cements, and glass [66]. The characteristics of the spatial distribution of Ba concentrations in the dust suggest that the Ba originated mostly from natural sources but with some contribution from industrial emissions and construction.

The third group contained only Co. The CV of Co concentrations was relatively high, and Co concentrations in the urban dust were clearly higher than the corresponding background concentrations for Shaanxi soil, demonstrating that Co concentrations in the urban dust were mainly governed by human activity. The location of Co hot-spots, however, differed from those of the other metals, and the low-low patterns of Co were in the central zone, indicating that the sources of Co pollution differed from those of the first group of metals. The Co hot-spots were mainly in the southwestern area, which contains high-tech industries and many buildings. Co is extensively used in coating materials, paints, and pigments that are common in industrial products and modern buildings due to their gloss, faultless color, and visual impact. Co is thus prevalent in the southwestern high-tech industrial area, the hot-spot of Co in the campus dust.

The last group contained only $\mathrm{Cr}$, whose concentrations were highly variable and were 2.5 -fold higher than the corresponding background concentration. Cr concentrations in the dust were thus likely mainly due to human activity. $\mathrm{Cr}$ had few hot-spots north of the inner ring road and south of the second ring road, where traffic is heavy and population density is high. $\mathrm{Cr}$ is extensively used in automobile parts and aluminum and titanium alloys [16]. The characteristics of the distribution of $\mathrm{Cr}$ hot-spots suggest that the $\mathrm{Cr}$ in the campus dust originated mainly from automobile emissions and the combustion of fossil fuels.

\section{Conclusions}

The dusts from kindergarten, elementary school, middle school, and university campuses in $\mathrm{Xi}^{\prime}$ an had elevated metal concentrations, especially those of $\mathrm{Pb}, \mathrm{Zn}, \mathrm{Co}, \mathrm{Cu}, \mathrm{Cr}$, and $\mathrm{Ba}$, which were 1.7-23.1, 0.9-26.5, 1.8-7.7, 1.0-6.5, 1.2-6.4, and 1.1-4.3-fold higher, respectively, than the corresponding background concentrations in Shaanxi soil. $\mathrm{Mn}, \mathrm{Ni}, \mathrm{V}, \mathrm{As}$, and Ba concentrations were generally low, and the $\mathrm{Co}, \mathrm{Cr}, \mathrm{Cu}, \mathrm{Pb}$, and $\mathrm{Zn}$ in the campus dust, especially $\mathrm{Pb}$ and $\mathrm{Zn}$, were mostly due to human activity.

The distribution of hot-spots differed among the metals. $\mathrm{As}, \mathrm{Cu}, \mathrm{Mn}, \mathrm{Ni}, \mathrm{Pb}, \mathrm{V}$, and $\mathrm{Zn}$ had important high-high patterns in the center of the city. The $\mathrm{Cu}, \mathrm{Pb}$, and $\mathrm{Zn}$ hot-spots were strongly influenced by traffic. The high-high patterns of As, $\mathrm{Mn}, \mathrm{Ni}$, and $\mathrm{V}$ in the central zone were due to both human activity and natural factors. The Co hot-spots were mainly associated with industrial and construction activity. The Ba and Cr hot-spots were irregular in the Xi'an urban area. The concentrations and uses of the metals suggest that Ba originated mainly from natural sources but with some contribution from industrial emissions. Cr accumulated in the campus dust due to traffic and fossil-fuel combustion. The local governments should strengthen the monitoring and management of pollutants discharged from vehicles, fossil-fuel combustion, industrial products, and construction sites in the future.

Acknowledgments: This research was supported by the National Natural Science Foundation of China (Grant 41271510), China Postdoctoral Science Foundation (Grant 2015M582605) and the Fundamental Research Funds for the Central University (Grants GK201503060 and GK201601009). Guang Yang and Caifeng Zhao assisted with sample preparation. We also thank the local school authorities for their cooperation.

Author Contributions: Xinwei Lu and Hao Chen conceived and designed the experiments, Tianning Gao and Yuyu Chang performed the experiments, Xinwei Lu and Hao Chen analyzed the data and Hao Chen wrote the paper.

Conflicts of Interest: The authors declare no conflict of interest. The funding sources had no role in the study design, collection, analysis, or interpretation of the data or the writing of the manuscript. 


\section{References}

1. Hien, P.D.; Binh, N.T.; Truong, Y.; Ngo, N.T. Temporal variations of source impacts at the receptor, as derived from air particulate monitoring data in Ho Chi Minh City, Vietnam. Atmos. Environ. 1999, 33, 3133-3142. [CrossRef]

2. Tanner, P.A.; Ma, H.L.; Yu, P.K. Fingerprinting metals in urban street dust of Beijing, Shanghai, and Hong Kong. Environ. Sci. Technol. 2008, 42, 7111-7117. [CrossRef] [PubMed]

3. Schleicher, N.J.; Norra, S.; Chai, F.; Chen, Y.; Wang, S.; Cen, K.; Yu, Y.; Stüben, D. Temporal variability of trace metal mobility of urban particulate matter from Beijing-A contribution to health impact assessments of aerosols. Atmos. Environ. 2011, 45, 7248-7265. [CrossRef]

4. Zhai, Y.; Li, P.; Zhu, Y.; Xu, B.; Peng, C.; Wang, T.; Li, C.; Zeng, G. Source apportionment coupled with gas/particle partitioning theory and risk assessment of polycyclic aromatic hydrocarbons associated with size-segregated airborne particulate matter. Water Air Soil Pollut. 2016, 227, 1-15. [CrossRef]

5. Langer, S.; Weschler, C.J.; Fischer, A.; Bekö, G.; Toftum, J.; Clausen, G. Phthalate and PAH concentrations in dust collected from Danish homes and daycare centers. Atmos. Environ. 2010, 44, 2294-2301. [CrossRef]

6. Lu, X.; Wang, L.; Li, L.Y.; Lei, K.; Huang, L.; Kang, D. Multivariate statistical analysis of heavy metals in street dust of Baoji, NW China. J. Hazard. Mater. 2010, 173, 744-749. [CrossRef] [PubMed]

7. Zheng, N.; Liu, J.; Wang, Q.; Liang, Z. Heavy metals exposure of children from stairway and sidewalk dust in the smelting district, northeast of China. Atmos. Environ. 2010, 44, 3239-3245. [CrossRef]

8. Li, N.; Xia, T.; Nel, A.E. The role of oxidative stress in ambient particulate matter-induced lung diseases and its implications in the toxicity of engineered nanoparticles. Free Radic. Biol. Med. 2008, 44, 1689-1699. [CrossRef] [PubMed]

9. Ruiz-Jimenez, J.; Parshintsev, J.; Laitinen, T.; Hartonen, K.; Petäjä, T.; Kulmala, M.; Riekkola, M.L. Influence of the sampling site, the season of the year, the particle size and the number of nucleation events on the chemical composition of atmospheric ultrafine and total suspended particles. Atmos. Environ. 2012, 49, 60-68. [CrossRef]

10. Hu, X.; Zhang, Y.; Ding, Z.; Wang, T.; Lian, H.; Sun, Y.; Wu, J. Bioaccessibility and health risk of arsenic and heavy metals (Cd, $\mathrm{Co}, \mathrm{Cr}, \mathrm{Cu}, \mathrm{Ni}, \mathrm{Pb}, \mathrm{Zn}$ and $\mathrm{Mn})$ in TSP and PM2. 5 in Nanjing, China. Atmos. Environ. 2012, 57, 146-152. [CrossRef]

11. Chillrud, S.N.; Epstein, D.; Ross, J.M.; Sax, S.N.; Pederson, D.; Spengler, J.D.; Kinney, P.L. Elevated airborne exposures to manganese, chromium and iron of teenagers from steel dust and New York City's subway system. Environ. Sci. Technol. 2004, 38, 732-737. [CrossRef] [PubMed]

12. Khairy, M.A.; Barakat, A.O.; Mostafa, A.R.; Wade, T.L. Multielement determination by flame atomic absorption of road dust samples in Delta Region, Egypt. Microchem. J. 2011, 97, 234-242. [CrossRef]

13. Lu, X.; Zhang, X.; Li, L.Y.; Chen, H. Assessment of metals pollution and health risk in dust from nursery schools in Xi'an, China. Environ. Res. 2014, 128, 27-34. [CrossRef] [PubMed]

14. Liu, X.; Zhai, Y.; Zhu, Y.; Liu, Y.; Chen, H.; Li, P.; Peng, C.; Xu, B.; Li, C.; Zeng, G. Mass concentration and health risk assessment of heavy metals in size-segregated airborne particulate matter in Changsha. Sci. Total Environ. 2015, 517, 215-221. [CrossRef] [PubMed]

15. Chen, H.; Lu, X.; Chang, Y.; Xue, W. Heavy metal contamination in dust from kindergartens and elementary schools in Xi'an, China. Environ. Earth Sci. 2014, 71, 2701-2709. [CrossRef]

16. Chen, H.; Lu, X.; Li, L.Y. Spatial distribution and risk assessment of metals in dust based on samples from nursery and primary schools of Xi'an, China. Atmos. Environ. 2014, 88, 172-182. [CrossRef]

17. Chen, H.; Lu, X.; Li, L.Y.; Gao, T.; Chang, Y. Metal contamination in campus dust of Xi'an, China: A study based on multivariate statistics and spatial distribution. Sci. Total Environ. 2014, 484, 27-35. [CrossRef] [PubMed]

18. McGrath, D.; Zhang, C.; Carton, O.T. Geostatistical analyses and hazard assessment on soil lead in Silvermines area, Ireland. Environ. Pollut. 2004, 127, 239-248. [CrossRef] [PubMed]

19. Franco, C.; Soares, A.; Delgado, J. Geostatistical modeling of heavy metal contamination in the topsoil of Guadiamar river margins (S Spain) using a stochastic simulation technique. Geoderma 2006, 136, 852-864. [CrossRef]

20. Liu, X.; $\mathrm{Wu}, \mathrm{J} . ; \mathrm{Xu}, \mathrm{J}$. Characterizing the risk assessment of heavy metals and sampling uncertainty analysis in paddy field by geostatistics and GIS. Environ. Pollut. 2006, 141, 257-264. [CrossRef] [PubMed] 
21. Hu, K.; Li, H.; Li, B.; Huang, Y. Spatial and temporal patterns of soil organic matter in the urban-rural transition zone of Beijing. Geoderma 2007, 141, 302-310. [CrossRef]

22. Anselin, L. Local Indicators of Spatial Association-LISA. Geogr. Anal. 1995, 27, 93-115. [CrossRef]

23. Boots, B. Local measures of spatial association. Ecoscience 2002, 9, 168-176.

24. Dale, M.R.; Fortin, M.J. Spatial autocorrelation and statistical tests in ecology. Ecoscience 2002, 9, $162-167$.

25. Zhang, C.; Luo, L.; Xu, W.; Ledwith, V. Use of local Moran's I and GIS to identify pollution hotspots of Pb in urban soils of Galway, Ireland. Sci. Total Environ. 2008, 398, 212-221. [CrossRef] [PubMed]

26. Ruiz, M.O.; Tedesco, C.; McTighe, T.J.; Austin, C.; Kitron, U. Environmental and social determinants of human risk during a West Nile virus outbreak in the greater Chicago area, 2002. Int. J. Health Geogr. 2004, 3, 1-11. [CrossRef] [PubMed]

27. Goovaerts, P.; Jacquez, G.M. Accounting for regional background and population size in the detection of spatial clusters and outliers using geostatistical filtering and spatial neutral models: The case of lung cancer in Long Island, New York. Int. J. Health Geogr. 2004, 3, 1-23. [CrossRef] [PubMed]

28. James, W.L.; Cossman, R.E.; Cossman, J.S.; Campbell, C.; Blanchard, T. A brief visual primer for the mapping of mortality trend data. Int. J. Health Geogr. 2004, 3, 1-17. [CrossRef] [PubMed]

29. McLaughlin, C.C.; Boscoe, F.P. Effects of randomization methods on statistical inference in disease cluster detection. Health Place 2007, 13, 152-163. [CrossRef] [PubMed]

30. McGrath, D.; Zhang, C. Spatial distribution of soil organic carbon concentrations in grassland of Ireland. Appl. Geochem. 2003, 18, 1629-1639. [CrossRef]

31. Zhang, C.; McGrath, D. Geostatistical and GIS analyses on soil organic carbon concentrations in grassland of southeastern Ireland from two different periods. Geoderma 2004, 119, 261-275. [CrossRef]

32. Zhang, X.Y.; Arimoto, R.; Cao, J.J.; An, Z.S.; Wang, D. Atmospheric dust aerosol over the Tibetan Plateau. J. Geophys. Res. Atmos. 2001, 106, 18471-18476. [CrossRef]

33. Han, Y.; Du, P.; Cao, J.; Posmentier, E.S. Multivariate analysis of heavy metal contamination in urban dusts of Xi'an, Central China. Sci. Total Environ. 2006, 355, 176-186.

34. Lu, X.; Li, L.Y.; Li, N.; Yang, G.; Luo, D.; Chen, J. Chemical characteristics of spring rainwater of Xi'an City, NW China. Atmos. Environ. 2011, 45, 5058-5063. [CrossRef]

35. Tonooka, Y.; Liu, J.; Kondou, Y. A survey on energy consumption in rural households in the fringes of $\mathrm{Xi}^{\prime}$ an City. Energy Build. 2006, 38, 1335-1342. [CrossRef]

36. Xi'an Municipal Bureau of Statistics. In Xi'an Statistical Yearbook in 2014; China Statistics Press: Beijing, China, 2015. (In Chinese)

37. Akhter, M.S.; Madany, I.M. Heavy metals in street and house dust in Bahrain. Water Air Soil Pollut. 1993, 66, 111-119. [CrossRef]

38. Lu, X.; Li, L.Y.; Wang, L.; Lei, K.; Huang, J.; Zhai, Y. Contamination assessment of mercury and arsenic in roadway dust from Baoji, China. Atmos. Environ. 2009, 43, 2489-2496. [CrossRef]

39. Lu, X.; Wang, L.; Lei, K.; Huang, J.; Zhai, Y. Contamination assessment of copper, lead, zinc, manganese and nickel in street dust of Baoji, NW China. J. Hazard. Mater. 2009, 161, 1058-1062. [CrossRef] [PubMed]

40. Dos Anjos, M.J.; Lopes, R.T.; de Jesus, E.F.O.; Assis, J.T.; Cesareo, R.; Barradas, C.A.A. Quantitative analysis of metals in soil using X-ray fluorescence. Spectrochim. Acta Part B Atomic Spectrosc. 2000, 55, 1189-1194. [CrossRef]

41. Hartyáni, Z.; Dávid, E.; Szabó, S.; Szilágyi, V.; Horváth, T.; Tóth, Á.H. Determination of the trace elements distribution of polluted soils in Hungary by X-ray methods. Microchem. J. 2000, 67, 195-200. [CrossRef]

42. Li, X.P.; Huang, C.C.; Pang, J.L. A rapid and simultaneous detection heavy metal pollutants in soil around storage cell manufactory: XRF spectroscopy. Phys. Test Chem. Anal. B Chem. Anal. XRF Spec. 2005, 41, 83-86. (In Chinese)

43. Zhang, C.; Selinus, O.; Schedin, J. Statistical analyses for heavy metal contents in till and root samples in an area of southeastern Sweden. Sci. Total Environ. 1998, 212, 217-232. [CrossRef]

44. Müller, G. Schwermetalle in den Sedimenten des Rheins-Veränderungenseit 1971. Umschau 1979, 79, 778-783.

45. Feng, S.; Liu, H.; Zhang, N.; Lin, H.; Du, X.; Liu, Y. Contamination assessment of copper, lead, zinc and chromium in dust fall of Jinan, NE China. Environ. Earth Sci. 2012, 66, 1881-1886. [CrossRef]

46. Kong, S.; Lu, B.; Ji, Y.; Zhao, X.; Chen, L.; Li, Z.; Han, B.; Bai, Z. Levels, risk assessment and sources of PM 10 fraction heavy metals in four types dust from a coal-based city. Microchem. J. 2011, 98, 280-290. [CrossRef] 
47. China National Environmental Monitoring Center. The Background Values of Elements in Chinese Soils; Environmental Science Press: Beijing, China, 1990. (In Chinese)

48. Krishna, A.K.; Govil, P.K. Assessment of heavy metal contamination in soils around Manali industrial area, Chennai, Southern India. Environ. Geol. 2008, 54, 1465-1472. [CrossRef]

49. Huo, X.N.; Zhang, W.W.; Sun, D.F.; Li, H.; Zhou, L.D.; Li, B.G. Spatial pattern analysis of heavy metals in Beijing agricultural soils based on spatial autocorrelation statistics. Int. J. Environ. Res. Public Health 2011, 8, 2074-2089. [CrossRef] [PubMed]

50. Box, G.E.P.; Cox, D.R. An analysis of transformations. J. Royal Stat. Soc. Ser. B 1964, 26, 211-252.

51. Jobson, J.D. Applied Multivariate Data Analysis, Regression and Experimental Design; Springer: New York, NY, USA, 1991.

52. Zhang, C.; Zhang, S. A robust-symmetric mean: A new way of mean calculation for environmental data. GeoJournal 1996, 40, 209-212. [CrossRef]

53. Zhai, Y.; Liu, X.; Chen, H.; Xu, B.; Zhu, L.; Li, C.; Zeng, G. Source identification and potential ecological risk assessment of heavy metals in PM 2.5 from Changsha. Sci. Total Environ. 2014, 493, 109-115. [CrossRef] [PubMed]

54. Lee, C.S.L.; Li, X.; Shi, W.; Cheung, S.C.N.; Thornton, I. Metal contamination in urban, suburban, and country park soils of Hong Kong: A study based on GIS and multivariate statistics. Sci. Total Environ. 2006, 356, 45-61. [CrossRef] [PubMed]

55. Anselin, L.; Syabri, I.; Kho, Y. GeoDa: An Introduction to spatial data analysis. Geogr. Anal. 2006, 38, 5-22. [CrossRef]

56. Li, X.Y.; Chen, T.B.; Lei, M.; Xie, Y.F.; Zhou, G.; Song, B. Concentrations and risk of heavy metals in surface soil and dust in urban squares and school campus in Beijing. Geogr. Res. 2010, 29, 989-996. (In Chinese)

57. Meza-Figueroa, D.; de la O-Villanueva, M.; de la Parra, M.L. Heavy metal distribution in dust from elementary schools in Hermosillo, Sonora, México. Atmos. Environ. 2007, 41, 276-288. [CrossRef]

58. Tong, S.T.; Lam, K.C. Are nursery schools and kindergartens safe for our kids? The Hong Kong study. Sci. Total Environ. 1998, 216, 217-225. [CrossRef]

59. Wang, X.; Ma, J.; Hou, Q.; Duan, H. Accumulation and health risk assessment of heavy metals in kindergarten surface dust in the city of Kaifeng. Acta Sci. Circumstantiate 2011, 31, 583-593. (In Chinese)

60. Darus, F.M.; Nasir, R.A.; Sumari, S.M.; Ismail, Z.S.; Omar, N.A. Heavy metals composition of indoor dust in nursery schools building. Procedia Soc. Behav. Sci. 2012, 38, 169-175. [CrossRef]

61. Saeedi, M.; Li, L.Y.; Salmanzadeh, M. Heavy metals and polycyclic aromatic hydrocarbons: Pollution and ecological risk assessment in street dust of Tehran. J. Hazard. Mater. 2012, 227, 9-17. [CrossRef] [PubMed]

62. Yang, Z.; Lu, W.; Long, Y.; Bao, X.; Yang, Q. Assessment of heavy metals contamination in urban topsoil from Changchun City, China. J. Geochem. Explor. 2011, 108, 27-38. [CrossRef]

63. Li, X.; Lee, S.L.; Wong, S.C.; Shi, W.; Thornton, I. The study of metal contamination in urban soils of Hong Kong using a GIS-based approach. Environ. Pollut. 2004, 129, 113-124. [CrossRef] [PubMed]

64. Chen, X.; Lu, X.; Yang, G. Sources identification of heavy metals in urban topsoil from inside the Xi'an Second Ringroad, NW China using multivariate statistical methods. Catena 2012, 98, 73-78. [CrossRef]

65. De Miguel, E.; Llamas, J.F.; Chacón, E.; Berg, T.; Larssen, S.; Røyset, O.; Vadset, M. Origin and patterns of distribution of trace elements in street dust: Unleaded petrol and urban lead. Atmos. Environ. 1997, 31, 2733-2740. [CrossRef]

66. Monaci, F.; Bargagli, R. Barium and other trace metals as indicators of vehicle emissions. Water Air Soil Pollut. 1997, 100, 89-98. [CrossRef]

(C) 2016 by the authors; licensee MDPI, Basel, Switzerland. This article is an open access article distributed under the terms and conditions of the Creative Commons Attribution (CC-BY) license (http://creativecommons.org/licenses/by/4.0/). 